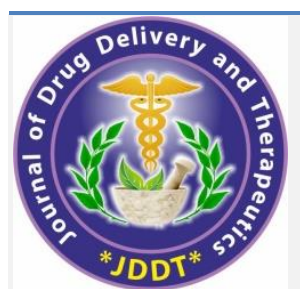

2

Open Access Full Text Article
Available online on 15.10.2021 at http://jddtonline.info

\section{Journal of Drug Delivery and Therapeutics}

Open Access to Pharmaceutical and Medical Research

Copyright (C) 2021 The Author(s): This is an open-access article distributed under the terms of the CC BY-NC 4.0 which permits unrestricted use, distribution, and reproduction in any medium for non-commercial use provided the original author and source are credited

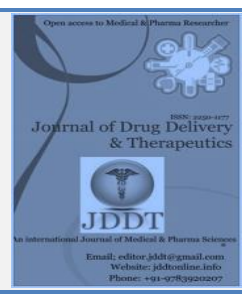

Research Article

\title{
Role and Efficacy of "Katankateriyadi Kwatha" in Patients of Madhumeha (Diabetes Mellitus Type 2): A Clinical Trial
}

\author{
Vandana Singh *, Bhuwal Ram \\ Department of Dravyaguna, Faculty of Ayurveda, IMS, BHU, Varanasi, 221005, India
}

\section{Article Info:

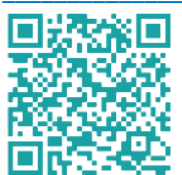 \\ Article History: \\ Received 13 August 2021 Reviewed 24 September 2021 Accepted 30 September 2021 Published 15 October 2021}

\section{Cite this article as:}

Singh V, Ram B, Role and Efficacy of "Katankateriyadi Kwatha" in Patients of Madhumeha (Diabetes Mellitus Type 2): A Clinical Trial, Journal of Drug Delivery and Therapeutics. 2021; $11(5-S): 25-32$

DOI: http://dx.doi.org/10.22270/jddt.v11i5-S.5085

\section{Abstract}

Madhumeha (Diabetes Mellitus) is a by-product of urbanization, proclaimed thousands of years back by Acharya Charaka. India has a high prevalence of diabetes which is increasing in number at an alarming rate. The introduction of oral hypoglycaemic drugs in modern therapeutics materialize to be a breakthrough in the treatment of Diabetes Mellitus initially but subsequently, it was experienced that most of the hypoglycaemic drugs were inadequately effective and were associated with many major side effects. To get rid of this problem, here we aimed to find out an effective and safe remedy to control the disease. This study is an Open-label, standard control, randomized and comparative clinical study with the 3-month assessment of the response of the trial drug "Katankateriyadi Kwatha" on the diabetic patients through subjective and objective parameters.

Keywords: Diabetes mellitus, Clinical study, Madhumeha, Katankateriyadi Kwatha.

*Address for Correspondence:

Dr. Vandana Singh, Research scholar, Department of Dravyaguna, Faculty of Ayurveda, IMS, BHU, Varanasi, 221005, India

\section{INTRODUCTION}

In the field of research, though experimental studies provide a better understanding regarding the efficacy, mode, and site of action of the drugs, the evaluation of the drugs is incomplete until they tried clinically. As a part of research work, the clinical study is very much essential to establish the effect of the drug.

Madhumeha (Diabetes mellitus-2) is worldwide a stubborn disease condition recognized by ancient scholars of ancient India. The Ayurvedic classical texts namely the Samhitas of Charaka, Susruta, Vagbhata and the subsequent treatises have invariably given a detailed description of the disease Prameha, its causes, types, pathology and the line of management in both preventive and curative aspects. Acharya Charaka has classified it into two groups i.e. Sthula Pramehi and Krisha Pramehi and Santarpanajanya and Aptarpanajanya Prameha at the other places $\mathbf{1}$. It can be paralleled with the classification given by Vagbhata i.e. Dhatukshayajanya Madhumeha and Avaranajanya Madhumeha respectively. The factor which elicits Vata directly causes Aptarpanajanya Madhumeha while the factor which elicits Kapha and Pitta causes Santarpanajanya Madhumeha. In Avaranajanya Madhumeha, Kapha is the prevailing dosha while the important dushyas are Meda and Kleda. In Avaranajanya Samprapti the vitiated Kapha and Pitta obstruct the patha of Vata causing its aggravation ${ }^{2}$. Acharya Susruta mentioned that in Madhumeha the vitiated doshas remains situated in the lower part of the body owing to the inefficiency of various Dhamanis ${ }^{3}$.

As Diabetes is not merely a metabolic syndrome, it gives rise to lethal complications too, that is why health authorities of all over the world and in all countries are trying best to take control over the spread of this disease. Research on remedies of diabetes mellitus is a continuous process being adopted by all countries. Our work was instigated to explore the possibility of better control over diabetes.

Ayurveda has described that it is not rational treatment where medicine modifies one disease; on the other hand, it provokes new complaints. So the effort has been made here to search the safe and effective medicine, without any side effects.

Considering the above-stated fact, a compound formulation of plant-derived, which has been used since ancient times to alleviate this disorder, i.e. Madhumeha (Diabetes mellitus-2) is selected. The formulation composed of six medicinal herbs namely; Daruharidra (stem), Yastimadhu (stem), Chitraka (root), Haritaki (Fruit), Bibhitaka (Fruit) and Amalaki (Fruit) and is known as "Katankateriyadi Kwatha". After the collection of the useful parts of the plants following the guidelines, the drug was prepared. 
Table 1: The individual properties of the trial drug (Katankateriyadi Kwatha) are intervened as:

\begin{tabular}{|l|}
\hline Rasa - Katu, Tikta, Kashaya (Madhura rasa in Yastimadhu) \\
\hline Guna - Laghu, Ruksha \\
\hline Vipaka - Katu (Daruharidra \& Chitraka) and Madhura \\
\hline Virya - Ushna (shita virya in Yastimadhu \& Amalaki) \\
\hline Dosha Karma - Tridoshaghna \\
\hline
\end{tabular}

\section{AIMS AND OBJECTIVES}

- To evaluate the role of Katankateriyadi kwatha in Madhumeha (Diabetes Mellitus-2).

- To determine the symbiotic relationship between Katankateriyadi kwatha and anti-hyperglycemic drug (Gliclazide SR).

\section{MATERIAL AND METHODS}

Selection of Patients: 75 cases of DM II (out of 85, 10 were drop out) registered from the O.P.D. of Department of Dravyaguna, Sir Sundarlal Hospital, Banaras Hindu University, and Varanasi. Some of these cases were already known diabetics while some cases were diagnosed for the first time when they visited with other complaints.

Pre-Treatment Observation: All the patients were studied at the time of registration considering their age, sex, religion, marital status, occupation, habitat, family history, dietary habits (diet habit-1 and diet habit-2), appetite, bowel habit, addiction, duration of illness and physical activity. After preliminary registration, patients were subjected to document their detail case history taking and physical examination including general and systemic examination.

Diagnostic Criteria: All the patients were examined clinically for signs and symptoms of Madhumeha (type 2 Diabetes mellitus) i.e; Prabhuta mutrata (polyuria), Kshudhadhikya (polyphagia), Trishnadhikya (polydipsia), Daurbalya (weakness), Karapadatala Suptata (numbness of limbs), Karapadatala Daha (tingling and burning sensation in sole and palm) and Pindikodweshtana (cramps in legs) over few months ${ }^{4}$. The entire patients were subjected to their fasting and postprandial blood sugar, $\mathrm{HbA}_{1} \mathrm{C}$, and lipid profile, etc.

\section{- Inclusion Criteria}

1. Male and female patients within the age limit 25-60 yrs.

2. Newly diagnosed patients with type 2 diabetes mellitus (Madhumeha).

3. Patients already taking oral hypoglycaemic drugs.

\section{- Exclusion Criteria}

1. Patients having age more than 60 yrs.

2. Patients having type1 DM.
3. Patients with severe complications of Diabetes (Nephropathy, Cardiomyopathy, Retinopathy, Neuropathy, etc.).

4. Patients having a superinfection.

5. Any other chronic diseases like Tuberculosis, Rheumatic Heart disease, Rheumatoid arthritis, etc.

6. Patients of type 2 DM taking insulin were also not included in the study.

7. Pregnant women and patients advised any surgical interventions.

Laboratory Investigations: The entire patients were subjected to their following biochemical investigations.

1. Fasting Blood sugar (FBS)

2. Post-Prandial Blood sugar (PPBS)

3. $\mathrm{HbA1C}$

4. Lipid profile

Study Design: An Open-label, standard control, randomized and comparative clinical trial.

- Sample Size - 75 patients registered divided into 3 groups

- Dropouts -10 patients

- Duration of Treatment - 3 months

- Follow Up - 30 days interval with 3 follow-ups

- Source of Formulation: The yavkuta churna of katankateriyadi kashaya was prepared in Ayurvedic pharmacy of Faculty of Ayurveda, Institute of Medical Sciences, Banaras Hindu University.

- Interventions

1. Drug \& Dose:- The trial drug Katankateriyadi kwatha $\mathbf{5}$ was advised to the patients. Coarse powder of plant parts approx. $40 \mathrm{~g}$ taken and four times water is added and boiled till one-fourth remain and this decoction is given two times. The standard drug i.e; Gliclazide SR $60 \mathrm{mg}$ advised twice a day before meal.

2. Duration:- All the patients were followed up at an interval of every 15 days. The total duration of treatment was 3 months.

- Criteria of Assessment of Overall Effect of Treatment: Selected patients were counseled to come for follow-ups at every one-month interval for three months. The assessment was done under the headings subjective and objective parameters.

i. The clinical symptomatology of the selected patients was divided into four grades (0-3) and changes in gradations of each symptom were assessed at each follow-up.

ii. Control on sugar levels for both fasting and aftermeal was focused at each follow-up.

iii. Improvement in HbA1C level and lipid profile was analyzed after the last follow-up i.e, 3 months. 
Table 2: Composition of Trial Drug Katankateriyadi Kwatha.

\begin{tabular}{|c|l|l|l|l|}
\hline S.No. & Drug name & Botanical name & Useful part & Part used \\
\hline 1. & Daruharidra & Berberis aristata DC. & Stem & 1 part \\
\hline 2. & Yastimadhu & Glycyrrhiza glabra Linn. & Stem & 1 part \\
\hline 3. & Chitraka & Plumbago zeylanica Linn. & Root & 1 part \\
\hline 4. & Haritaki & Terminalia chebula Retz. & Fruit & 1 part \\
\hline 5. & Bibhitaki & Terminalia bellirica Roxb. & Fruit & 1 part \\
\hline 6. & Amalaki & Emblica officinalis Gaertn. & Fruit & 1 part \\
\hline
\end{tabular}

\section{Treatment Protocol}

Group A: Katankateriyadi kwatha group; Mild to moderate cases of madhumeha (type 2 diabetes) were advised with Katankateriyadi kwatha along with pathya-apathya as per protocol.

Group B: Control group; Known patients of madhumeha (type 2 diabetes) were administered with oral hypoglycaemic drug (Gliclazide SR-60 mg) along with recommended pathya-apathya as per protocol.

Group C: Integrative group; Known patients of madhumeha (type 2 diabetes) already taking the Gliclazide SR (60 mg BD) but not well under control were advised with Katankateriyadi kwatha additionally along with pathyaapathya as per protocol.

Patients of all the groups were counseled to follow pathaapathya as given $\mathbf{6}^{\text {: }}$

\section{Pathya}

- Ahara - Yava (barley), green gram, moong dal, all green and leafy vegetables, anyone seasonal fruit daily, 2 chapattis each meal.

- Vihara - daily 2-3 km brisk walking in the morning

\section{Apathya}

- Ahara - milk and milk products, dried fruits, chocolates, sugar, rice, bakery products, potatoes and oily and fried food.

- Vihara - avoid sleeping in the day time.

\section{Ethical Clearance}

A detailed research proforma was prepared to incorporate all the points from Ayurvedic as well as a modern aspect to study the patients as well as disease. The study had received prior approval from the Institutional ethics committee. (ECR/526/Inst/UP/2014 Dt. 31.1.14).

\section{Statistical Analysis}

Significant enhancement in the subjective criteria in a single group was assessed by the Friedman test and to compare the effect of the drug between the groups was done by the Chisquare test. Similarly for the improvement of the clinical parameters within the group was judged by paired t-test and comparison between the groups was carried out by one way ANOVA.

\section{OBSERVATION AND RESULTS}

Statistical analysis of their general profile evidenced the majority of cases belongs to the age group 41-60 yrs. (65.3\%) asserting that disease Madhumeha has a predominance of occurrence at middle age group whereas, the onset of the disease was also observed in the younger age group i.e, $20-30$ yrs. (9.3\%). Also, more male cases (65.3\%) were registered as compared to female cases (34.7\%). Married cases (68\%) were in more incidences and Hindu cases $(80 \%)$ were registered in a large number. Prevalence of disease was remarked more in-service class individuals $(38.7 \%)$ contribute to the fact that a sedentary lifestyle (Asyasukhama) 7 and work stress is one of the causes of Madhumeha, followed by housewife (28.0\%) indicating altered food habits to be one of the dominating cause. Highly marked cases belonged to urban areas (81.3\%) illuminating diabetes to be a modern lifestyle disorder. Out of which mostly belongs to middle economic status, it shows its more prevalence in the middle socioeconomic status group. As people of the middle socioeconomic group have to face more stress in their daily lives, diabetes seems to be closely related to stress.

Nearly about $33.3 \%$ of cases were having a family history of diabetes contributed to the fact that disease has a genetic predisposition.

The personal profile of the patients elucidates statistical incidence with more cases having a non-vegetarian diet $(54.7 \%)$ which contributed to the fact that overindulgence in Mansa $\mathbf{8}$ is one of the causes of madhumeha and the majority with altered bowel habits (50.7\%). Maximum cases had no addiction (62.7\%) with an average $4-10 \%$ cases was observed with alcohol, Tobacco, smoking and other addiction. It also reveals that apathya ahara, vihara contribute to the development of disease in diabetic prone peoples. Marked cases were having a history of diabetes for $>6$ yrs $(40 \%)$ with a moderately active lifestyle (62.7\%) followed by $16 \%$ of patients with a sedentary lifestyle which again supports the review data that showed decreased physical activity (ekasthanarati) ${ }^{9}$ as the leading cause of increasing type-2 diabetes mellitus prevalence.

The demography of the clinical profile of the patients was statistically analyzed in each group and also between the groups. About $64 \%$ of cases in group A had mild to moderate grade of Prabhuta mutrata (Polyurea) induced due to excess of vitiated kleda initially before treatment as compared to $76 \%$ in group B and $48 \%$ in group C. Nearly $40 \%$ cases in group A were observed with mild to moderate Trishnadhikya (polydipsia) occurs due to Pitta vriddhi and udaka kshaya initially before treatment followed by $72 \%$ in group B and $56 \%$ in group C. Nearly $60 \%, 68 \%$ and $48 \%$ cases in group $1^{\text {st }}, 2^{\text {nd }}$ and $3^{\text {rd }}$ group respectively had mild to moderate Kshudhadhikya (polyphagia) caused due to Tikshna and ushna guna of Pitta initially before treatment. The majority of cases were observed with $0-4 \mathrm{~kg}$ loss of weight/year i.e; $88 \%$ in group $1^{\text {st }}$ initially before treatment followed by $74 \%$ and $88 \%$ in group $2^{\text {nd }}, 3^{\text {rd }}$ respectively. In the etiopathogenesis of Prameha, the Dhatus get vitiated, resulting in Dhatukshaya responsible for the manifestation of Daurbalya (weakness), 
Pindikodweshtana (cramps in legs). Approximate 45-55\% cases in all the groups suffered from mild to moderate Pindikodweshtana (leg cramps) before treatment. Karapadatala Daha and Karapadatala Suptata (burning sensation and numbness in the palm and foot) are both reported as Purvarupa of Prameha in the Ayurvedic literature. About $50-60 \%$ of cases in all groups had mild to moderate Karapadatala Daha (tingling and burning sensation) initially before treatment. Nearly $60 \%$ of cases suffered from mild to moderate Karapadatala Suptata (numbness) in group $1^{\text {st }}$ initially before treatment followed by $44 \%$ and $48 \%$ in group $2^{\text {nd }}$ and $3^{\text {rd }}$ respectively.

All the groups have shown significant relief in all the symptoms in successive follow-ups. Intergroup comparison was found statistically highly significant in symptoms polyuria, polyphagia and tingling \& burning sensation. The absence of symptoms was higher in group $\mathrm{C}$ as compared to other groups. The overall improvement was determined based on the percentage of presence and absence of symptoms after treatment as compared to before treatment.

1. If no. of symptoms absent is up to $50 \%$, the improvement is considered mild.

2. If no. of symptoms absent is $>50 \&<75 \%$, the improvement is considered as moderate.

3. If no. of symptoms absent is $>75 \%$, then it is considered as a marked improvement.

Table 3: Overall Improvement based on the presence of eight symptoms before and after treatment:

\begin{tabular}{|c|c|c|c|c|}
\hline \multirow[t]{2}{*}{ Improvement } & \multicolumn{3}{|c|}{ No. \& (\%) of cases } & \multirow[t]{2}{*}{$\mathbf{X}^{2}$} \\
\hline & Group 1 & Group 2 & Group 3 & \\
\hline No change $(0 \%)$ & $2(9.52)$ & $0(0)$ & $0(0)$ & \multirow{5}{*}{$\begin{array}{c}\chi^{2}=8.40, \\
d f=2, \\
p=0.015\end{array}$} \\
\hline Mild ( $\leq 50 \%)$ & $5(23.80)$ & $7(36.84)$ & $3(14.28)$ & \\
\hline Moderate (51-74.9\%) & $4(19.04)$ & $8(42.10)$ & $4(19.04)$ & \\
\hline Marked ( $\geq 75 \%)$ & $10(47.61)$ & $4(21.05)$ & $14(66.66)$ & \\
\hline Total & $21(100)$ & $19(100)$ & $21(100)$ & \\
\hline
\end{tabular}

The above table shows marked improvement in overall symptoms in patients of group $3^{\text {rd }}$ nearly $66.66 \%$ as compared to group $1^{\text {st }}$, and $2^{\text {nd }}$ after the last follow-up which is statistically highly significant.

Effect of Trial Drug on FBS: All the groups have shown a highly significant $(\mathrm{p} \leq 0.001)$ decrease in mean FBS by
$69.126,62.963$ and 89.519 in group $1^{\text {st }}, 2^{\text {nd }}$, and $3^{\text {rd }}$ respectively at the last follow-up. The intergroup comparison was not statistically significant after treatment indicating that all the groups are equally effective in reducing fasting blood sugar.

Table 4 Showing effect of treatment on FBS level

\begin{tabular}{|c|c|c|c|c|c|}
\hline \multirow[t]{2}{*}{ Groups } & \multicolumn{4}{|c|}{$\begin{array}{c}\text { FBS } \\
(\text { mean } \pm \text { std.deviation })\end{array}$} & \multirow{2}{*}{$\begin{array}{c}\text { Comparison within the group } \\
\text { Paired t-test } \\
\text { (BT-AT) }\end{array}$} \\
\hline & BT & F1 & F2 & F3 & \\
\hline Group 1 & $\begin{array}{r}179.14 \\
\pm 47.119\end{array}$ & $\begin{array}{r}149.86 \\
\pm 43.160\end{array}$ & $\begin{array}{r}123.90 \\
\pm 32.168\end{array}$ & $\begin{array}{r}106.90 \\
\pm 16.742\end{array}$ & $\begin{array}{c}69.126 \pm 35.828 \\
t=8.842 \\
p=0.000\end{array}$ \\
\hline Group 2 & $\begin{array}{r}171.75 \\
\pm 21.835\end{array}$ & $\begin{array}{r}141.89 \\
\pm 19.591\end{array}$ & $\begin{array}{r}120.73 \\
\pm 17.473\end{array}$ & $\begin{array}{r}106.41 \\
\pm 13.823\end{array}$ & $\begin{array}{c}62.963 \pm 21.028 \\
t=13.052 \\
p=0.000\end{array}$ \\
\hline Group 3 & $\begin{array}{c}191.67 \\
\pm 50.007\end{array}$ & $\begin{array}{r}146.58 \\
\pm 34.795\end{array}$ & $\begin{array}{r}121.92 \\
\pm 32.511\end{array}$ & $\begin{array}{r}103.66 \\
\pm 16.381\end{array}$ & $\begin{array}{c}89.519 \pm 43.976 \\
t=9.329 \\
p=0.000\end{array}$ \\
\hline $\begin{array}{l}\text { Comparison } \\
\text { between the group } \\
\text { One-way ANOVA }\end{array}$ & $\begin{array}{l}F=1.463 \\
p=0.238\end{array}$ & $\begin{array}{l}F=0.348 \\
p=0.708\end{array}$ & $\begin{array}{l}F=0.069 \\
p=0.934\end{array}$ & $\begin{array}{l}F=0.254 \\
p=0.776\end{array}$ & \\
\hline
\end{tabular}


Effect of Trial Drug on PPBS: Decrease in mean PPBS at $3^{\text {rd }}$ follow-up as compared to before treatment is 124.756 , 106.353 and 127.024 in $1^{\text {st }}, 2^{\text {nd }}$ and $3^{\text {rd }}$ group respectively; which were statistically highly significant. All the groups are equally effective in reducing post-prandial blood sugar as the intergroup comparison shows insignificant results.

Table 5 Showing effect of treatment on PPBS level

\begin{tabular}{|l|c|c|c|c|c|}
\hline \multicolumn{1}{|c|}{ Groups } & \multicolumn{3}{|c|}{ PPBS } & $\begin{array}{c}\text { Comparison within the } \\
\text { group } \\
\text { Paired t-test } \\
\text { (mean } \pm \text { std.deviation) }\end{array}$ \\
\cline { 2 - 6 } & BT & F1 & F2 & F3 \\
\hline Group 1 & 294.27 & 229.64 & 183.91 & 160.29 & $124.756 \pm 38.526$ \\
& \pm 42.070 & \pm 48.170 & \pm 25.002 & \pm 16.378 & $\mathrm{t}=14.840, \mathrm{p}=0.000$ \\
\hline Group 2 & 277.29 & 217.62 & 188.18 & 171.26 & $106.353 \pm 21.028$ \\
& \pm 18.149 & \pm 32.169 & \pm 23.556 & \pm 14.163 & $\mathrm{t}=21.151, \mathrm{p}=0.000$ \\
\hline Group 3 & 289.05 & 223.51 & 181.22 & 165.80 & $127.024 \pm 49.753$ \\
& \pm 61.485 & \pm 46.673 & \pm 33.579 & \pm 32.546 & $\mathrm{t}=11.700, \mathrm{p}=0.000$ \\
\hline $\begin{array}{l}\text { Comparison between } \\
\text { the group One-way }\end{array}$ & $\mathrm{F}=0.966$ & $\mathrm{~F}=0.490$ & $\mathrm{~F}=0.342$ & $\mathrm{~F}=1.156$ & \\
\hline
\end{tabular}

Effect of Trial Drug on HbA1C: Decrease in mean $\mathrm{HbA}_{1} \mathrm{C}$ after treatment as compared to before treatment is 1.8095 , 1.3158 and 2.1095 in group $1^{\text {st }}, 2^{\text {nd }}$, and $3^{\text {rd }}$ respectively; which were statistically highly significant. Intergroup comparison was not found significant after the treatment.

Table 6 Showing effect of treatment on HbA1C level

\begin{tabular}{|c|c|c|c|}
\hline \multirow[t]{2}{*}{ Groups } & \multicolumn{2}{|c|}{$\begin{array}{c}\text { HbA1C } \\
\text { (mean } \pm \text { std.deviation) }\end{array}$} & \multirow{2}{*}{$\begin{array}{c}\text { Comparison within the group } \\
\text { Paired t-test } \\
\text { (BT-AT) }\end{array}$} \\
\hline & BT & F3 & \\
\hline Group 1 & $8.576 \pm 1.5791$ & $6.686 \pm 0.4328$ & $\begin{array}{l}1.8095 \pm 1.3323 \\
t=6.224, p=0.000\end{array}$ \\
\hline Group 2 & $7.928 \pm 0.5842$ & $6.711 \pm 0.4677$ & $\begin{array}{l}1.3158 \pm 0.5659 \\
t=10.134, p=0.000\end{array}$ \\
\hline Group 3 & $8.612 \pm 2.1324$ & $6.638 \pm 0.3866$ & $\begin{array}{l}2.1095 \pm 2.0557 \\
t=4.703, p=0.000\end{array}$ \\
\hline $\begin{array}{l}\text { Comparison between the } \\
\text { group One-way ANOVA }\end{array}$ & $\begin{array}{l}F=1.505 \\
p=0.229\end{array}$ & $\begin{array}{l}F=0.149 \\
p=0.862\end{array}$ & \\
\hline
\end{tabular}

Effect of Trial Drug on Lipid Profile: All the groups have shown significant improvement in their lipid profile levels after treatment. Total cholesterol level (Decrease in mean after treatment is $82.938,63.316$ and 64.476 in groups 1 st, $2^{\text {nd }}$ and $3^{\text {rd }}$ respectively ) and triglyceride (Decrease in mean after $3^{\text {rd }}$ follow-up is 56.400, 24.579 and 34.524 in groups $1^{\text {st }}, 2^{\text {nd }}$ and $3^{\text {rd }}$ respectively ) was statistically highly significant within the group \& not significant in intergroup comparison. In both cases group $1^{\text {st }}$ shows significant improvement as compared to other groups.

The value of HDL (Increase in mean after treatment is 9.586, 7.474 and 8.905 in groups $11^{\text {st }}, 2^{\text {nd }}$ and $3^{\text {rd }}$ respectively) was statistically highly significant within the group and also found significant in intergroup comparison showing significant control in HDL with trial drug in synergistic action with standard drug as compared to the standard drug i.e; value of HDL was increased in group $\mathrm{C}$ after taking treatment.

In all groups reduction in LDL (Decrease in mean after $3^{\text {rd }}$ follow-up is $23.862,15.158$ and 23.895 in groups $1^{\text {st }}, 2^{\text {nd }}$ and $3^{\text {rd }}$ respectively) and VLDL level (Decrease in mean after $3^{\text {rd }}$ follow-up is $18.9238,13.0526$ and 10.2571 in groups $1^{\text {st }}, 2^{\text {nd }}$ and $3^{\text {rd }}$ respectively) was statistically highly significant within the group \& not significant in intergroup comparison. The trial drug was found more effective in controlling LDL and VLDL as compared to the standard drug. 
Table 7 Showing effect of treatment on Cholesterol level

\begin{tabular}{|l|c|c|c|}
\hline \multirow{2}{*}{ Groups } & \multicolumn{2}{|c|}{$\begin{array}{c}\text { Cholesterol } \\
\text { (mean } \pm \text { std.deviation) }\end{array}$} & $\begin{array}{c}\text { Comparison within the group } \\
\text { Paired t-test } \\
\text { (BT-AT) }\end{array}$ \\
\cline { 2 - 4 } & BT & $166.48 \pm 32.816$ & $82.938 \pm 47.629$ \\
$\mathrm{t}=7.980, \mathrm{p}=0.000$
\end{tabular}

Table 8 Showing effect of treatment on Triglyceride level

\begin{tabular}{|c|c|c|c|}
\hline \multirow[t]{2}{*}{ Groups } & \multicolumn{2}{|c|}{$\begin{array}{c}\text { Triglyceride } \\
\text { (mean } \pm \text { std.deviation) }\end{array}$} & \multirow{2}{*}{$\begin{array}{c}\text { Comparison within the group } \\
\text { Paired t-test } \\
\text { (BT-AT) }\end{array}$} \\
\hline & BT & F3 & \\
\hline Group 1 & $190.86 \pm 92.843$ & $139.43 \pm 40.185$ & $\begin{array}{l}56.400 \pm 64.268 \\
T=4.022, P=0.001\end{array}$ \\
\hline Group 2 & $148.80 \pm 17.673$ & $123.68 \pm 7.048$ & $\begin{array}{l}24.579 \pm 17.995 \\
\mathrm{~T}=5.954, \mathrm{P}=0.000\end{array}$ \\
\hline Group 3 & $174.24 \pm 52.113$ & $141.14 \pm 31.257$ & $\begin{array}{l}34.524 \pm 31.406 \\
\mathrm{~T}=5.037, \mathrm{P}=0.000\end{array}$ \\
\hline $\begin{array}{l}\text { Comparison between the } \\
\text { group One-way ANOVA }\end{array}$ & $\begin{array}{l}F=2.889 \\
p=0.062\end{array}$ & $\begin{array}{l}F=2.000 \\
p=0.145\end{array}$ & \\
\hline
\end{tabular}

Table 9 Showing effect of treatment on HDL level

\begin{tabular}{|c|c|c|c|}
\hline \multirow[t]{2}{*}{ Groups/Tests } & \multicolumn{2}{|c|}{$\begin{array}{c}\text { Hdl } \\
\text { (mean } \pm \text { std.deviation) }\end{array}$} & \multirow{2}{*}{$\begin{array}{c}\text { Comparison within the group } \\
\text { Paired t-test } \\
\text { (BT-AT) }\end{array}$} \\
\hline & BT & F3 & \\
\hline Group 1 & $32.95 \pm 6.375$ & $43.10 \pm 6.147$ & $\begin{array}{c}-9.586 \pm 4.769 \\
t=-9.211, p=0.000\end{array}$ \\
\hline Group 2 & $31.20 \pm 4.796$ & $37.95 \pm 3.188$ & $\begin{array}{c}-7.474 \pm 5.976 \\
t=-5.452, p=0.000\end{array}$ \\
\hline Group 3 & $34.00 \pm 11.937$ & $44.48 \pm 10.759$ & $\begin{array}{c}-8.905 \pm 5.431 \\
t=-7.517, p=0.000\end{array}$ \\
\hline $\begin{array}{l}\text { Comparison between the } \\
\text { group One-way ANOVA }\end{array}$ & $\begin{array}{l}F=0.728 \\
p=0.486\end{array}$ & $\begin{array}{l}F=4.153 \\
p=0.021\end{array}$ & \\
\hline $\begin{array}{l}\text { Post Hoc test } \\
1 \text { vs } 2 \\
1 \text { vs } 3 \\
2 \text { vs } 3\end{array}$ & & $\begin{array}{l}\mathrm{p}=0.102 \\
\mathrm{p}=1.000 \\
\mathrm{p}=0.024\end{array}$ & \\
\hline
\end{tabular}


Table 10 Showing effect of treatment on LDL level

\begin{tabular}{|c|c|c|c|}
\hline \multirow[t]{2}{*}{ Groups } & \multicolumn{2}{|c|}{$\begin{array}{c}\text { Ldl } \\
(\text { mean } \pm \text { std.deviation })\end{array}$} & \multirow{2}{*}{$\begin{array}{c}\text { Comparison within the group } \\
\text { Paired t-test } \\
\text { (BT-AT) }\end{array}$} \\
\hline & BT & F3 & \\
\hline Group 1 & $132.44 \pm 22.237$ & $106.19 \pm 18.471$ & $\begin{array}{l}23.862 \pm 13.350 \\
t=8.191, p=0.000\end{array}$ \\
\hline Group 2 & $128.12 \pm 17.259$ & $117.21 \pm 9.295$ & $\begin{array}{l}15.158 \pm 16.025 \\
t=4.123, p=0.001\end{array}$ \\
\hline Group 3 & $137.03 \pm 22.016$ & $111.14 \pm 19.767$ & $\begin{array}{l}23.895 \pm 16.882 \\
t=6.486, p=0.000\end{array}$ \\
\hline $\begin{array}{l}\text { Comparison between the } \\
\text { group } \\
\text { One-way ANOVA }\end{array}$ & $\begin{array}{l}F=1.166 \\
p=0.317\end{array}$ & $\begin{array}{l}F=2.171 \\
p=0.123\end{array}$ & \\
\hline
\end{tabular}

Table 11 Showing effect of treatment on VLDL level

\begin{tabular}{|l|c|c|c|}
\hline \multirow{2}{*}{ Groups } & \multicolumn{2}{|c|}{$\begin{array}{c}\text { VLDL } \\
\text { (mean } \pm \text { std.deviation) }\end{array}$} & $\begin{array}{c}\text { Comparison within the group } \\
\text { Paired t-test } \\
\text { (BT-AT) }\end{array}$ \\
\cline { 2 - 4 } & BT & F3 & $18.9238 \pm 15.7547$ \\
& 52.4448 & \pm 8.7712 & $13.0526 \pm 11.2915$ \\
\hline Group 1 & \pm 19.7489 & 34.316 & $\mathrm{t}=5.039, \mathrm{p}=0.000$ \\
\hline Group 3 & 45.160 & \pm 5.2605 & $10.2571 \pm 9.0382$ \\
$\mathrm{t}=5.201, \mathrm{p}=0.000$ \\
\hline Comparison between the & \pm 11.0517 & 33.619 & \pm 8.1699 \\
group & 42.856 & $\mathrm{~F}=0.302$ & \\
One-way ANOVA & $\mathrm{F}=2.844$ & $\mathrm{p}=0.740$ & \\
\hline
\end{tabular}

Therefore, the above-endorsed statistics signal that the test drug epitomizes to control the symptoms better than the standard drug. The study exemplifies that the trial drug is equally effective in controlling FBS, PPBS, and $\mathrm{HbA1C}$ as the standard drug, whereas the trial drug (in Group A) is more efficacious in the management of lipid profile as compared to other groups. These results materialize the pramehahar effect of the drugs Haritaki 10, Amalaki 11, Bibhitaki 12, Daruharidra 13, Chitraka ${ }^{14}$ and Yastimadhu ${ }^{15}$. Also proposed actions of the drugs like antioxidant, antistress, immunomodulator, the anti-atherosclerotic activity must also oversee to withstand against the symptomatological effects and complications of the disease.

\section{DISCUSSION}

Prameha is described to have contrived after the consumption of "havisha of yagya" performed by Daksha Prajapati. Its inclusion in "Ashta Mahagada" by Acharya Charaka, Susruta and Vagbhata marked the dominancy of the disease. "Prameho anusanginama" 16, contemplated by Acharya Charaka intimates the cohesive nature and poor prognosis of the disease. Based on its etiology and symptoms madhumeha can be co-related with Diabetes Mellitus type-2 (NIDDM-non insulin-dependent diabetes mellitus).
Prameha is contemplated to be kapha pradhan tridoshaja vyadhi. Here, the term kapha pradhan reveals that if all the three doshas are involved to produce prameha then it is kapha dosha which make body favourable for the genesis of prameha roga. It also unfolds the fact that in initial stage maximum patients suffer with kaphaja prameha which later on changes into vataja prameha \& pittaja prameha. The main dushya in any type of prameha are those components of body which can not only be vitiated by these dosha but could be brought to basti to vitiate mutra also i.e, 'Medo dhatu' and watery components are main dushya.

Therefore the drugs possessing properties opposite to that of kapha dosha and meda dhatu and are proficient enough to break the samprapti of the disease by intensifying agni, digesting ama, and cleansing the srotas are competent in opposing the prameha roga.

Katankateriyadi kwatha is amidst such type of drug. Probably katu and tikta rasa present in it are kapha shamak and agni deepak in nature and facilitates srotodushti while kasaya rasa hinders the movement of shariragata kleda towards basti. Presence of Ruksha guna directly pacifies kapha due to opposite in property. Laghu guna of this kwatha supports in digestion of amadosha by boosting vayu and agni mahabhuta. Tikshna guna of this drug is responsible of sroto suddhi and also perform lekhana karma to eliminate 
meda, kaphanashak karma and sodhan karma to remove mala rupa dosha. Ushna virya of most of the compound of this kwath pacifies kapha and vata dosha.

Pathya is highly advised along with other drugs in prameha because almost every dhatu (except asthi) and kleda of body might be dushya in prameha roga. Therefore patency and health of srotas inside the body for dhatusamyata in prameha rogi is highly necessary.

\section{CONCLUSION}

1. Safe and effective treatment of Madhumeha (DM-II) is much more challenging since very beginning till now because all drugs have their own limitations, in this connection a poly herbal formulation may be a good choice.

2. Katankateriyadi kwatha (a poly herbal formulation) has been used by Acharya Chakrpanidatta (11th cent A.D.) for the treatment of madhumeha.

3. After scientific study (overall objective and subjective assessment) observation were found more effective in group C (treated by both Katankateriyadi kwatha \& Gliclazide SR) than group A (treated by Katankateriyadi kwatha) and group B (treated by Gliclazide SR $60 \mathrm{mg}$ ) significantly due to synergistic effect.

4. Although the test drug epitomizes to control the symptoms better than the standard drug. No side effects were observed during treatment.

The aforesaid clinical trial gives positive output that Katankateriyadi Kwatha is effective in Madhumeha (DM-II), which needs a larger number of data to communicate Katankateriyadi Kwatha as one of the convalescent and potent compound formulation of vegetable origin drug in madhumeha. Therefore, appropriate ahara-vihara along with the Ayurvedic drugs solitarily or in combination with the modern drugs depending on the necessity provide enduring health benefits in the patients of Madhumeha (Diabetes mellitus).

\section{Conflict of Interest - Nil}

\section{REFERENCES}

1. Acharya Jadavaji Trikamji Vaidya, Editor (reprint edition), Charak Samhita of Agnivesa, Varanasi, Chaukhambha Prakashan, 2009.

2. Asatanga Hridyam, Edited With 'Nirmala' Hindi Commentary, By Brahmanand Tripathi, Chaukhamba Sanskrit Pratisthan, Delhi, Edition Reprint 2011.

3. Sharma PV, Editor (reprint edition), Susruta Samhita with English translation of text and Dalhana's commentary along with critical notes, Chikitsasthana $12 / 8$, Varanasi, Chaukhambha Visvabharati, 2010

4. Acharya Jadavaji Trikamji Vaidya, Editor (reprint edition), Charak Samhita of Agnivesa, Varanasi, Chaukhambha Prakashan, 2009.

5. Chakradatta 35/23 Tripathi Dr. Indradev, 'Vaidhprabha' Hindi commentary on Chakradatta, Edited by Prof. Ramanath Dwivedi, Varanasi, Chaukhamba Sanskrit Santhan, 2011.

6. Acharya Jadavaji Trikamji Vaidya, Editor (reprint edition), Charak Samhita of Agnivesa, Sutrasthana 25, Varanasi, Chaukhambha Prakashan, 2009.

7. Acharya Jadavaji Trikamji Vaidya, Editor (reprint edition), Charak Samhita of Agnivesa, Sutrasthana 25, Varanasi, Chaukhambha Prakashan, 2009.

8. Acharya Jadavaji Trikamji Vaidya, Editor (reprint edition), Charak Samhita of Agnivesa, Nidanasthan 4, Varanasi, Chaukhambha Prakashan, 2009.

9. Acharya Jadavaji Trikamji Vaidya, Editor (reprint edition), Charak Samhita of Agnivesa, Sutrasthan 19, Varanasi, Chaukhambha Prakashan, 2009.

10. Murali, Y.K., Ramesh Chander, and Murthy, P.S. Antyhyperglycemic effect of water extract of dry fruits of Terminalia chebula in experimental diabetes mellitus. Ind. J. Clin. Biochem. 2004; 19:202- 204. https://doi.org/10.1007/BF02894285

11. Anila L, Vijaylakshmi NR; Flavonoids from Emblica officinalis and Mangifera indica-effectiveness for dyslipidemia, Journal of Ethnopharmacology, 2002; 79(1):81-87. https://doi.org/10.1016/S0378-8741(01)00361-0

12. Latha RC, Daisy P. Insulin-secretagogue, antihyperlipidemic and other protective effects of gallic acid isolated from Terminalia bellerica Roxb. In streptozotocin-induced diabetic rats. Chemicobiological interactions. 2011; 15;189 (1):112-8. https://doi.org/10.1016/j.cbi.2010.11.005

13. Semwal, B \& Shah K, Chauhan M, Badhe R, Divakar K. Antidiabetic activity of stem bark of Berberis aristata D.C. in alloxan induced diabetic rats. Internet Journal of Pharmacology. 2008; 6 . https://doi.org/10.5580/90

14. Christudas S, Duraipandiyan V, Agastian P, Ignacimuthu, S, Antidiabetic effect of plumbagin isolated from Plumbago zeylanica L. root and its effect on GLUT4 translocation in streptozotocin-induced diabetic rats. Food and chemical toxicology: an international journal published for the British Industrial Biological Research Association. 2012; 50:4356-4363. https://doi.org/10.1016/j.fct.2012.08.046

15. Karthikeson et al.; Anti-Diabetic Activity of Glycyrrhiza glabra An In vitro Study, Int. J. Pharm. Sci. Rev. Res., 2017; 44(1):80-81.

16. Acharya Jadavaji Trikamji Vaidya, Editor (reprint edition), Charak Samhita of Agnivesa, Sutrasthana 25, Varanasi, Chaukhambha Prakashan, 2009. 